\title{
The Use of Learning Videos to Improve the Skills in Writing Environmental Observation Results for Class II Students
}

\author{
Riska Rahmita \\ SD Negeri 2 Kritig \\ riska97rahmi@gmail.com
}

\section{Article History}

accepted 01/11/2020

approved 08/11/2020

published 15/11/2020

\begin{abstract}
This research has the aim of increasing the skills to write reports on the results of simple environmental observations. The subjects of this study were class II SD Negeri 2 Kritig, totaling 15 students. This research was conducted in 3 cycles. Each cycle consists of 4 stages, namely planning, implementing and observing, and reflecting. There are two assessments carried out in this study, namely an assessment of the content of the report and an assessment of the writing. The results of his research for the assessment of report content in the first cycle of completeness reached $80 \%$ and increased in cycles II and III to reach $100 \%$. Then for the written assessment, completeness reached $26.67 \%$ in the first cycle increased to $67 \%$ in the second cycle and $86.7 \%$ in the third cycle. Furthermore, the average final score in cycle I reached 73.99, increased to 78.75 in cycle II and reached 80.2 in cycle III. So the conclusion is that through the use of instructional video media it can improve the skills of writing reports on environmental observations of grade II students of SD Negeri 2 Kritig.
\end{abstract}

Keywords: writing skills, environmental observation reports, learning videos

\begin{abstract}
Abstrak
Penelitian ini mempunyai tujuan yaitu meningkatkaj keterampilan menulis laporan hasil pengamatan lingkungan sederhana. Subjek penelitian ini adalah kelas II SD Negeri 2 Kritig yang berjumlah 15 siswa. Penelitian ini dilaksanakan dalam 3 siklus. Setiap siklus terdiri dari 4 tahapan yakni perencanaan, pelaksanaan dan pengamatan, serta refleksi. Ada dua penilaian yang dilaksanakan dalam penelitian ini, yaitu penilaian mengenai isi laporan dan penilaian mengenai tulisan. Adapun hasil penelitiannya untuk penilaian isi laporan pada siklus I ketuntasan mencapai $80 \%$ dan meningkat pada siklus II dan III mencapai $100 \%$. Kemudian untuk penilaian tulisan, ketuntasan mencapai $26,67 \%$ pada siklus I meningkat menjadi $67 \%$ pada siklus II, dan $86,7 \%$ pada siklus III. Selanjutnya untuk rata-rata nilai akhir pada siklus I mencapai 73,99 meningkat menjadi 78,75 pada siklus II, dan mencapai 80,2 pada siklus III. Sehingga kesimpulannya adalah melalui penggunaan media video pembelajaran dapat meningkatkan keterampilan menulis laporan hasil pengamatan lingkungan siswa kelas II SD Negeri 2 Kritig.
\end{abstract}

Kata Kunci: keterampilan menulis, laporan pengamatan lingkungan, video pembelajaran

Social, Humanities, and Education Studies (SHEs): Conference Series https://jurnal.uns.ac.id/shes

p-ISSN 2620-9284

e-ISSN 2620-9292 


\section{PENDAHULUAN}

Pembelajaran Bahasa Indonesia diarahkan untuk meningkatkan kemampuan siswa dalam menyimak, membaca, berbicara, dan menulis. Keterampilan yang harus dikuasai siswa SD sejak dini adalah keterampilan menulis permulaan, dikarenakan keterampilan menulis permulaan adalah keterampilan yang mendasar bagi siswa SD. Kemampuan dan pengetahuan yang didapati siswa pada pembelajaran menulis permulaan akan menjadi dasar dalam peningkatan dan pengembangan kemampuan siswa pada jenjang selanjutnya. Apabila pembelajaran menulis permulaan baik sebagai pedoman maka diharapkan hasil pengembangan keterampilan menulis sampai tingkat selanjutnya akan menjadi baik pula. Keterampilan menulis permulaan dipelajari di kelas I, II, dan III. Idealnya, siswa kelas II SD sudah mampu menulis dengan baik. Hal tersebut karena mengingat pembelajaran menulis permulaan yang fokus pada keterampilan berakhir di kelas II SD. Fokus pembelajaran menulis di kelas berikutnya sudah tidak pada keterampilan cara menulis huruf, namun lebih mengarah ke pengembangan tulisan.

Menurut Dalman (2014:3, dalam Diyah), menulis merupakan kegiatan yang bertujuan untuk menyampaikan pesan dari satu pihak ke pihak lain dengan menggunakan bahasa tulis sebagai alatnya. Melalui menulis, seseorang dapat menuangkan gagasan dalam bahaasa tulis dengan tujuan menyampaikan, memberitahu atau menghibur. Menulis mencakup kegiatan merangkai huruf menjadi kata atau kalimat untuk disampaikan kepada orang lain. Menulis merupakan salah satu keterampilan berbahasa yang digunakan untuk berkomunikasi secara tidak langsung serta merupakan kegiatan produktif dan akspresif (Tarigan, 2008:3, dalam Diyah). Abdulrahman, dkk (2000, dalam Naiswa: 2017) menjelaskan bahwa "menulis merupakan penggambaran visual tentang pikiran, perasaan dan ide dengan menggunakan bahasa tulis untuk keperluan komunikasi untuk menyampaikan pesan tertentu". Hal ini juga diperkuat oleh Wahyudi (2011: 76, dalam Naiswa: 2017) mengungkapkan bahwa "menulis ialah menurunkan atau melukiskan lambanglambang grafik yang menggambarkan suatu bahasa yang dipahami oleh seseorang sehingga orang lain dapat menyampaikan makna, tetapi tidak menggambarkan kesatuan bahasa". Sedangkan Hadiyanto (2001: 9-10, dalam Naiswa: 2017), mengemukakan bahwa "menulis merupakan usaha atau kegiatan yang dilakukan oleh seorang penulis untuk mengungkapkan fakta-fakta, perasaan, sikap, dan isi pikirannya secara jelas dan efektif, kepada pembaca".

Namun, pelaksanaan di lapangan menunjukkan bahwa pembelajaran menulis tidak semudah yang dibayangkan dan hasilnya pun juga tidak seideal yang diharapkan apalagi di masa pandemi Covid-19 seperti ini. Tentunya akan lebih sulit lagi untuk membelajarkan ke siswa tentang cara menulis yang baik. Masih banyak siswa kelas II yang belum lancar menulis. Permasalahan-permasalahan yang ditemui sebagai berikut ini. Pertama, sebagian besar siswa kesulitan dalam menulis huruf lepas sesuai dengan bentuk dan ukuran proporsionalnya. Kedua, beberapa siswa diketahui kurang lengkap dalam menuliskan huruf penyusun kata. Ketiga, beberapa siswa belum mampu mengeja kata yang didiktekan guru, sehingga siswa kesulitan dalam menuliskan kata tersebut apalagi menyangkut menulis hasil pengamatan.

Berdasarkan hasil wawancara dengan guru kelas II SD Negeri 2 Kritig memang selama pandemi ini masih kurang dalam pembelajaran terutama menulis. Guru hanya memberi ceramah dalam pembelajaran dan guru juga hanya memberi contoh saja. Jadi guru masih kesulitan untuk menemukan cara yang tepat untuk membelajarkan menulis yang baik dan benar mengacu laporan hasil pengamatan. Namun di SD Negeri 2 Kritig khususnya pada kelas II, umumnya anak belum dapat merangkai kata menjadi kalimat, penulisan kurang baik dan kurang jelas sehingga dalam penulisan kata maupun kalimat kadang hurufnya tidak cukup atau tidak lengkap sehingga menghambat mereka dalam membacanya. Jika hal ini terus dibiarkan, maka 
dikhawatirkan pada kelas berikutnya siswa akan lebih sulit lagi dalam kegiatan menulis laporan hasil pengamatan sederhana.

Berangkat dari permasalahan tersebut, diperlukan sebuah solusi agar dapat membantu guru dalam memecahkan permasalahan yang terjadi. Solusinya adalah menggunakan media pembelajaran yang tepat untuk pembelajaran keterampilan menulis laporan hasil pengamatan lingkungan. Penggunaan media pembelajaran yang tepat merupakan salah satu kunci keberhasilan pembelajaran. Dalam hal ini peneliti akan menggunakan video pembelajaran dalam pembelajaran menulis laporan hasil pengamatan tentang lingkungan di kelas II SD Negeri 2 Kritig.

Terkait belum maksimalnya keetrampilan menulis siswa narasi, maka diperlukan solusi pemecahan yakni dengan penggunaan media video. Menurut Cheppy Riyana (2007, dalam Nella: 2016) media video pembelajaran adalah media yang menyajikan audio dan visual yang berisi pesan-pesan pembelajaran baik yang berisi konsep, prinsip, prosedur, teori aplikasi pengetahuan untuk membantu pemahaman terhadap suatu materi pembelajaran. Film dan video dapat melengkapi pengalaman-pengalaman dasar dari siswa ketika mereka membaca, berdiskusi, praktik, dan lain-lain (Kustandi, 2011: 73, dalam Diyah). Tidak dapat dipungkiri bahwa pengunaan media dapat memberikan kesan kepada siswa. Video juga merupakan bahan ajar non cetak yang kaya informasi dan tuntas karena dapat sampai ke hadapan siswa secara langsung (Daryanto, 2015: 86, dalam Diyah). Sedangkan pengamatan adalah sebuah kegiatan yang dilaksanakan secara sengaja dan terencana dengan maksud untuk mendapat informasi atas apa yang menjadi destinasi dalam pengamatan (Jatikom, 2017).

Penggunaan media terutama video nantinya diharapkan dapat menarik siswa dalam belajar menulis. Video membuat siswa mengamati sekaligus mendengarkan cerita yang disampaikan. Penggunaan media video ini memungkinkan proses komunikasi secara aktif, yakni penyampaian pesan dari guru ke siswa. Siswa lebih terfokus dan dapat memahami materi dengan mudah. Mereka nantinya akan diminta mengamati video yang diberikan oleh guru. Setelah itu, barulah siswa menuliskan menuliskan laporan hasil pengamatan dengan menggunakan bahasa sendiri. Video yang digunakan dalam penelitian ini adalah video tentang lingkungan yang bersih dan tidak bersih. Adapun kelebihan media video pembelajaran menurut Rizcy (2011) adalah mengatasi jarak dan waktu, dapat diulang-ulang, dan mampu mengembangkan pikiran dan imajinasi siswa. Sedangkan kelemahannya adalah proses pembuatannya lama, biaya yang dibutuhkan besar, dan peralatan yang dibutuhkan untuk membuatnya banyak.

Adapun permasalahan pada penelitian adalah bagaimana penggunaan video pembelajaran dapat meningkatkan keterampilan menulis laporan hasil pengamatan lingkungan bagi siswa kelas II SD Negeri 2 Kritig. Adapun Tujuan penelitian adalah meningkatkan keterampilan menulis laporan hasil pengamatan lingkungan melalui penggunaan video pembelajaran bagi siswa kelas II SD Negeri 2 Kritig. Pada KTSP (2018), pembelajaran menulis laporan hasil pengamatan lingkungan ada pada semester 1 muatan pelajaran Bahasa Indonesia KD 4.4 Menyajikan penggunaan kosakata Bahasa Indonesia yang tepat dan atau Bahasa daerah hasil pengamatan tentang lingkungan sehat dan lingkungan tidak sehat di lingkungan sekitar serta cara menjaga kesehatan lingkungan dalam bentuk teks tulis, lisan, dan visual. Dalam KD tersebut terdapat materi menulis laporan hasil pengamatan lingkungan.

Hasil penelitian ini diharapkan dapat memberikan manfaat bagi siswa dan guru. Pembatasan penelitian ini adalah media pembelajaran yang digunakan adalah video yang berisi tentang lingkunga yang bersih dan tidak bersih. Objek dalam penelitian ini adalah siswa kelas II SD Negeri 2 Kritig yang berjumlah 15 siswa, serta 
penilaian hanya pada aspek isi laporan dan tulisan saja karena siswa masih kelas II SD dan laporan yang ditulis masih dalam bentuk sederhana (Kemdikbud: 2017)

Penelitian yang relevan dengan penelitian ini adalah penelitian yang dilakukan oleh Diyah Suci Kusumaningrum (2017) yang berjudul "Penggunaan Media Video untuk Meningkatkan Keterampilan Menulis Narasi Siswa Kelas V SDN Palem 2 Ngawi. Dalam penelitiannya diperoleh hasil bahwa keaktifan pembelajaran mengalami peningkatan dari 68,1 menjadi 89,2 . Hasil belajar siswa mengalami peningkatan dari $67,7 \%$ menjadi 90,3\%. Jadi, kesimpulannya adalah melalui penggunaan media video dapat meningkatkan pelaksanaan pembelajaran dan hasil belajar menulis narasi siswa kelas V SDN Pelem 2 Ngawi.

\section{METODE}

Penelitian ini merupakan penelitian tindakan kelas yang dilaksanakan dalam tiga siklus yang setiap siklusnya terdiri dari tahap perencanaan, pelaksanaan, observasi, dan refleksi. Subjek penelitian ini adalah siswa kelas II SD Negeri 2 Kritig yang berjumlah 15 siswa yang terdiri dari 5 siswa laki-laki dan 10 siswa perempuan. Penelitian dilaksanakan di SD Negeri 2 Kritig mulai tanggal 19 Oktober 2020 - 15 November 2020. Teknik pengumpulan data yang dilakukan dengan menggunakan tes unjuk kerja menulis laporan hasil pengamatan lingkungan. Data yang dianalisis adalah data kuantitatif nilai hasil menulis laporan sederhana tentang lingkungan. Penilaian terdiri dari dua aspek yaitu aspek isi laporan dan aspek tulisan. Penelitian ini dikatakan berhasil apabila rata-rata nilai akhir adalah 75 dan siswa tuntas $80 \%$ dengan KKM 75.

\section{HASIL DAN PEMBAHASAN}

Penelitian tindakan kelas ini dilakukan untuk mengetahui bagaimana penggunaan video pembelajaran untuk meningkatkan keterampilan menulis laporan hasil pengamatan lingkungan. Penelitian tindakan kelas ini dilaksanakan dalam tiga siklus. Sebelum peneliti melaksanakan penelitian, terlebih dahulu mengadakan tes awal sebagai tolok ukur keberhasilan dan mengetahui kondisi awal sebelum tindakan dilakukan. Peneliti menetapkan KKM dalam penelitian tindakan ini adalah 75 dan indikator kinerja diharapkan tuntas KKM 80\% siswa. Hasil dari tes awal menunjukkan bahwa yang mencapai KKM hanya 9 siswa atau $60 \%$ dari 15 siswa yang mengikuti tes awal untuk penilaian isi laporan, sedangkan untuk penilaian tulisan ketuntasan baru mencapai $13,33 \%$. Dari tes awal ini diperoleh nilai rata-rata 65,47.

Pelaksanaan tindakan siklus I sudah berjalan dengan baik walaupun siswa belum terbiasa dengan suasana yang baru karena pembelajaran daring menggunakan zoom meeting, tetapi siswa dapat mengikuti kegiatan pembelajaran dengan baik. Yang dapat masuk zoom hanya satu kelompok. Guru kemudian memberi solusi dengan mengirimkan video pembelajaran melalui WAG. Hasil penilaian keterampilan menulis laporan pada tindakan siklus I sudah cukup bagus. Dari 15 siswa yang mengikuti pada siklus I, terdapat $80 \%$ yang sudah tuntas untuk penilaian isi laporan dan $26,67 \%$ untuk penilaian tulisan. Sedangkan rata-rata nilai pada siklus I adalah 73,99. Hasil ini sudah memenuhi indikator kinerja peneliti pada penilaian isi laporan, tetapi untuk persentase ketuntasan siswa mengenai penilaian tulisan belum memenuhi indikator kinerja peneliti, serta rata-rata nilai juga belum memenuhi. Dari hasil ini terdapat peningkatan yang signifikan antara hasil tes awal dengan hasil siklus I.

Pada pelaksanaan tindakan siklus II, pembelajaran juga berjalan dengan baik dan tertib. Kekurangan-kekurangan pada siklus I sudah diperbaiki. Siswa sudah mulai terbiasa dengan suasana kelas daring menggunakan zoom meeting. Guru sudah mulai 
dapat mengendalikan siswa dan suasana belajar juga kondusif. Siswa sangat antusias untuk menjawab pertanyaan yang diberikan guru. Hasil penilaian menulis laporan pada siswa yang mencapai KKM pada siklus II adalah 100\%, sedangkan untuk penilaian tulisan ketuntasan mencapai $67 \%$. Rata-rata nilai pada siklus II ini juga meningkat dibandingkan dengan siklus I, yaitu menjadi 78,75 yang sebelumnya 73,99. Berdasarkan hal ini, dapat dikatakan bahwa terdapat peningkatan yang signifikan. Hasil siklus II ini sudah memenuhi indikator peneliti untuk rata-rata nilai dan penilaian isi laporan, tetapi belum memenuhi untuk penilaian tulisan.

Kekurangan-kekurangan pada pelaksanaan siklus I dan II juga diperbaiki pada siklus III. Pelaksanaan siklus III juga berjalan dengan lancar dan tertib. Siswa sudah terbiasa dengan suasana belajarnya sehingga siswa lebih mudah memahami materi yang disampaikan guru. Dalam siklus III juga terdapat peningkatan hasil menulis laporan sederhana. Hal ini terbukti dengan penilaian hasil keterampilan menulis laporan juga meningkat dibanding siklus I dan II. Pada siklus III diperoleh rata-rata nilai 80,2 , sedangkan siswa yang mencapai KKM untuk penilaian isi laporan sudah mencapai $100 \%$ dan yang mencakapai KKM untuk penilaian tulisan mencapai $86,7 \%$. Dengan adanya video pembelajaran siswa menjadi lebih memahami dan dapat menuliskan hasil pengamatan lingkungan melalui video yang disajikan.

Dari penilaian hasil siklus I sampai III menunjukkan bahwa ada 2 siswa yang selalu mendapat nilai kurang dari KKM. Hal ini dikarenakan memang siswa tersebut lemah dalam memahami materi pembelajaran dan kurang aktif atau cenderung diam ketika mengikuti kegiatan pembelajaran walaupun peneliti sudah melakukan berbagai cara supaya siswa tersebut lebih aktif, misalnya dengan memberikan pertanyaan, mendekatinya, memotivasi, dan menyuruh berpendapat. Untuk itu di luar tindakan, peneliti memberikan bimbingan kepada siswa tersebut dengan latihan menulis.

Berdasarkan hasil analisis data dapat diperoleh hasil penelitian sebagai berikut:

Tabel 1. Perbandingan Rata-Rata Nilai Tiap Aspek Penilaian

\begin{tabular}{clccc}
\multirow{2}{*}{ No } & \multirow{2}{*}{ Aspek yang Dinilai } & \multicolumn{3}{c}{ Perbandingan Rata-Rata Nilai } \\
& & Siklus I & Siklus II & Siklus III \\
\hline 1. & Isi laporan & 81,3 & 84,5 & 85,4 \\
2. & Tulisan & 66,67 & 73 & 75 \\
\hline
\end{tabular}

Tabel 2. Perbandingan Persentase Ketuntasan Penilaian Keterampilan Menulis Laporan Hasil Pengamatan Lingkungan

\begin{tabular}{clccc}
\hline No & Aspek Kegiatan & Siklus I & Siklus II & Siklus III \\
\hline 1. & Isi laporan & $80 \%$ & $100 \%$ & $100 \%$ \\
2. & Tulisan & $26,67 \%$ & $67 \%$ & $86,7 \%$ \\
\hline
\end{tabular}

Tabel 3. Perbandingan Rata-Rata Nilai Akhir
No
Uraian Kegiatan
Rata-Rata Nilai Akhir 


\begin{tabular}{rlc}
\hline 1. & Tes Awal & 65,47 \\
2. & Siklus I & 73,99 \\
3. & Siklus II & 78,75 \\
4. & Siklus III & 80,2 \\
\hline
\end{tabular}

Untuk lebih jelasnya dari tabel perbandingan di atas, berikut peneliti sajikan dalam diagram mulai dari siklus I sampai siklus III yang disajikan dalam gambar berikut:

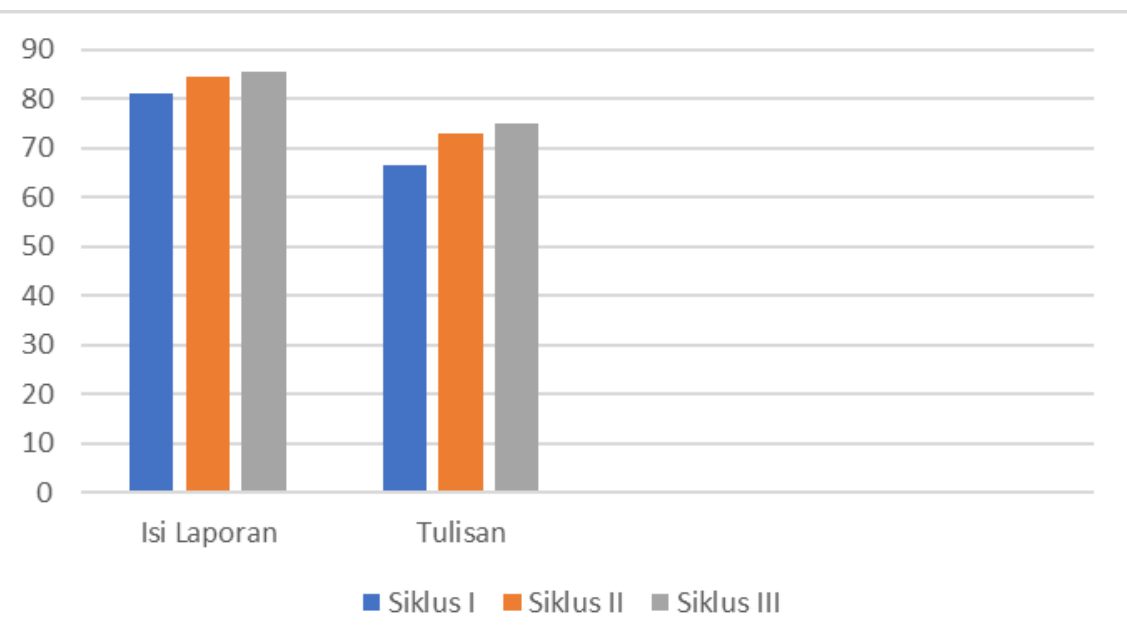

Gambar 1. Diagram Perbandingan Rata-Rata Nilai Tiap Aspek Penilaian

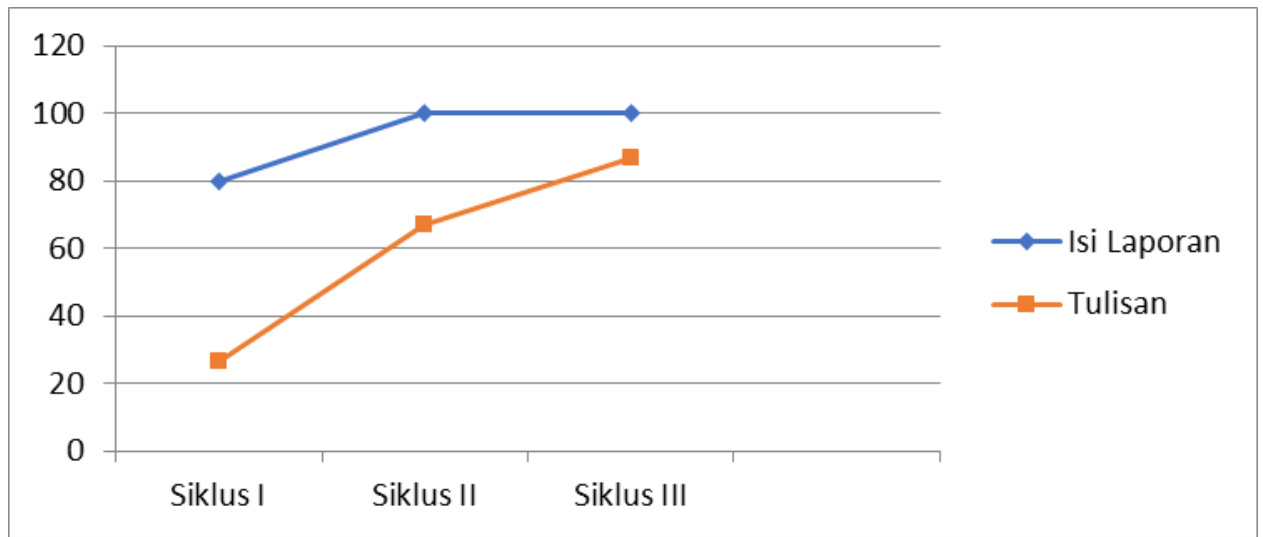

Gambar 2. Grafik Peningkatan Ketuntasan Belajar 


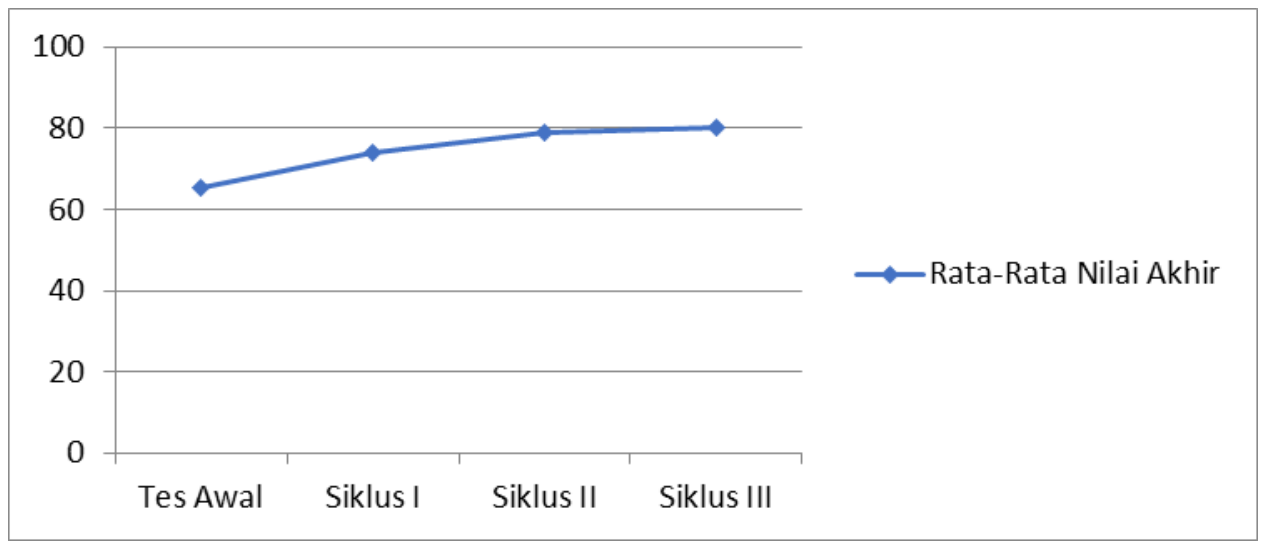

Gambar 3. Grafik Peningkatan Rata-Rata Nilai Akhir

Berdasarkan tabel tersebut di atas, mulai dari tes awal sampai siklus III terjadi peningkatan dalam hal penilaian keterampilan menulis siswa. Yang pertama peningkatan rata-rata nilai tiap aspek penilaian yaitu pada penilaian isi laporan pada siklus I mendapat 81,3 , kemudian naik menjadi 84,5 pada siklus II dan naik lagi menjadi 85,4 pada siklus III. Selanjutnya untuk penilaian tulisan diperoleh rata-rata nilai pada siklus I yaitu 66,67 naik menjadi 73 pada siklus II dan naik menjadi 75 pada siklus III. Kenaikan juga dialami pada persentase ketuntasan yaitu untuk penilaian isi laporan dari $80 \%$ pada siklus I menjadi $100 \%$ pada siklus II dan siklus III. Kemudian untuk persentase ketuntasan pada penilaian tulisan siklus I mendapat $26,67 \%$ naik menjadi $67 \%$ pada siklus II dan menjadi $86,7 \%$ pada siklus III. Selanjutnya perbandingan ratarata nilai akhir ketika tes awal diperoleh 65,47 kemudian naik menjadi 73,99 pada siklus I, naik menjadi 78,75 pada siklus II, kemudian mengalami kenaikan lagi pada siklus III menjadi 80,2. Pada siklus III penilaian tulisan tidak tuntas $100 \%$. Hal ini dikarenakan pada siklus III ada 2 siswa yang selalu mendapat nilai kurang dari KKM sejak tes awal sampai siklus III. Persentase ketuntasan pada siklus III sudah memenuhi indikator peneliti, yaitu $80 \%$ siswa tuntas dalam menulis laporan hasil pengamatan lingkungan secara sederhana.

Berdasarkan fakta tersebut dapat diambil kesimpulan bahwa penggunaan media video pembelajaran dapat meningkatkan keterampilan menulis laporan hasil pengamatan lingkungan di kelas II SD Negeri 2 Kritig. Hal ini selaras dengan hasil penelitian yang dilakukan oleh Diyah Suci Kusumaningrum (2017) yang berjudul "Penggunaan Media Video untuk Meningkatkan Keterampilan Menulis Narasi Siswa Kelas V SDN Palem 2 Ngawi. Keberhasilan tindakan ini juga sesuai dengan pendapat Cheppy Riyana (2007, dalam Nella: 2016) media video pembelajaran adalah media yang menyajikan audio dan visual yang berisi pesan-pesan pembelajaran baik yang berisi konsep, prinsip, prosedur, teori aplikasi pengetahuan untuk membantu pemahaman terhadap suatu materi pembelajaran. Film dan video dapat melengkapi pengalaman-pengalaman dasar dari siswa ketika mereka membaca, berdiskusi, praktik, dan lain-lain (Kustandi, 2011: 73, dalam Diyah). Dengan adanya video pembelajaran siswa menjadi lebih memahami dan dapat menuliskan hasil pengamatan lingkungan melalui video yang disajikan. 


\section{SIMPULAN}

Berdasarkan hasil analisis yang diperoleh dalam pelaksanaan penelitian tindakan kelas tentang penggunaan video pembelajaran untuk meningkatkan keterampilan menulis laporan hasil pengamatan lingkungan pada kelas II di SD Negeri 2 Kritig Tahun Pelajaran 2020/2021 dapat disimpulkan bahwa penggunaan video pembelajaran dapat meningkatkan keterampilan menulis laporan hasil pengamatan lingkungan pada kelas II di SD Negeri 2 Kritig Kecamatan Petanahan Kabupaten Kebumen Tahun Pelajaran 2020/2021.

Sehubungan dengan simpulan yang telah diperoleh, ada beberapa saran yang dapat dikemukakan peneliti yang kiranya dapat membangun demi kemajuan pendidikan, antara lain saran bagi guru dan peneliti. Guru dalam mengajarkan materi menuliskan laporan hasil pengamatan lingkungan sebaiknya menggunakan video pembelajaran. Perlu diadakan penelitian selanjutnya guna mengetahui pemanfaatan video pembelajaran dalam meningkatkan keterampilan menulis laporan hasil pengamatan lingkungan.

\section{DAFTAR PUSTAKA}

Jatikom. (2017). Pengertian dan Contoh Laporan Pengamatan, Struktur, Ciri. Diakses pada tanggal 1 November 2020 dari https://www.jatikom.com/pengertian-dancontoh-laporan/

Kemdikbud. (2017). Buku Guru Tema 4. Hidup Bersih dan Sehat Kelas 2. Jakarta: Kemdikbud

Kemdikbud. (2017). Buku Siswa Tema 4. Hidup Bersih dan Sehat Kelas 2. Jakarta: Kemdikbud

Kementrian Pendidikan dan Kebudayaan. (2018). Kurikulum Tingkat Satuan Pendidikan (KTSP). Kebumen: Kemdikbud.

Kusumaningrum, Diyah Suci. (2017). Penggunaan Media Video untuk Meningkatkan Keterampilan Menulis Narasi Siswa Kelas V SDN Pelem 2 Ngawi. Jurnal UNESA diakses dari www.neliti.com

Naiswa. (2017). Pengembangan Pembelajaran Keterampilan Menulis di Sekolah Dasar. Diakses pada tanggal 1 November 2020 dari http://pustakanaiswa.blogspot.com/2017/05/pengembangan-pembelajaran-keterampilan.html

Maynarani, Nella. (2016). Media Video Pembelajaran. Bangkalan. Diakses pada tanggal $11 \quad$ November $2020 \quad$ dari http://wanitacintaislam.blogspot.com/2016/09/makalah-media-videopembelajaran.html

Pangesti, Rizcy Hardy. (2011). Kelebihan dan Kelemahan Media Video Pembelajaran. Diakses pada tanggal 1 November 2020 dari https://rizcybl.wordpress.com/2011/01/07/kelebihan-dan-kelemahan-mediavideo-pembelajaran/ 